\title{
Hypothesis of the neuroendocrine cortisol pathway gene role in the comorbidity of depression, type 2 diabetes, and metabolic syndrome
}

\author{
This article was published in the following Dove Press journal: \\ The Application of Clinical Genetics \\ I April 2014 \\ Number of times this article has been viewed
}

\author{
Claudia Gragnoli ${ }^{1,2}$ \\ 'Center for Biotechnology and \\ Department of Biology, College \\ of Science and Technology, Temple \\ University, Philadelphia, PA, USA; \\ ${ }^{2}$ Molecular Biology Laboratory, Bios \\ Biotech Multi-Diagnostic Health \\ Center, Rome, Italy
}

\begin{abstract}
Depression, type 2 diabetes (T2D), and metabolic syndrome (MetS) are often comorbid. Depression per se increases the risk for T2D by $60 \%$. This risk is not accounted for by the use of antidepressant therapy. Stress causes hyperactivation of the hypothalamicpituitary-adrenal (HPA) axis, by triggering the hypothalamic corticotropin-releasing hormone $(\mathrm{CRH})$ secretion, which stimulates the anterior pituitary to release the adrenocorticotropin hormone (ACTH), which causes the adrenal secretion of cortisol. Depression is associated with an increased level of cortisol, and CRH and ACTH at inappropriately "normal" levels, that is too high compared to their expected lower levels due to cortisol negative feedback. T2D and MetS are also associated with hypercortisolism. High levels of cortisol can impair mood as well as cause hyperglycemia and insulin resistance and other traits typical of T2D and MetS. We hypothesize that HPA axis hyperactivation may be due to variants in the genes of the CRH receptors (CRHR1, CRHR2), corticotropin receptors (or melanocortin receptors, $M C 1 R-M C 5 R$ ), glucocorticoid receptor (NR3C1), mineralocorticoid receptor $(N R 3 C 2)$, and of the FK506 binding protein 51 (FKBP5), and that these variants may be partially responsible for the clinical association of depression, T2D and MetS. In this review, we will focus on the correlation of stress, HPA axis hyperactivation, and the possible genetic role of the CRHR1, CRHR2, MCR1-5, $N R 3 C 1$, and NR3C2 receptors and FKBP5 in the susceptibility to the comorbidity of depression, T2D, and MetS. New studies are needed to confirm the hypothesized role of these genes in the clinical association of depression, T2D, and MetS.
\end{abstract}

Keywords: depression, type 2 diabetes, metabolic syndrome, cortisol, CRH, ACTH

\section{Introduction}

Type 2 diabetes mellitus (T2D) is associated with an increase in the risk of major depressive disorder. ${ }^{1,2}$ Conversely, depression confers a $60 \%$ increased T2D risk. ${ }^{3}$ This association between depression and T2D cannot be attributed to antidepressant therapy. ${ }^{4}$ T2D is associated with metabolic syndrome (MetS), and T2D, MetS, and depression are associated with high cortisol levels. ${ }^{5-9}$ It is possible that neuroendocrine dysfunction in depression increases the risk for T2D and MetS, and that inherited gene variants involved in stress responses might account, at least in part, for the comorbidity of depression with T2D and MetS. ${ }^{6,10,11}$

In fact, considerable evidence suggests that genetic vulnerability to depression may be conferred by variation in genes regulating systems of stress response, ${ }^{12,13}$ such as the hypothalamic-pituitary-adrenal (HPA) axis. ${ }^{14,15}$ The HPA axis is a neuroendocrine
Correspondence: Claudia Gragnoli BioLife Science Bldg, Suite 43I, Center for Biotechnology, College of Science and Technology, Temple University, $1900 \mathrm{~N}$ 12th Street, Philadelphia, PA 19122, USA $\mathrm{Tel}+\mathrm{I} 5082469330$

$\mathrm{Fax}+$ I 7 I7 482 II 23

Email claudia.gragnoli@gmail.com 
system modulating the stress response via interactions with serotonergic, noradrenergic, and dopaminergic brain systems. Stress leads to high cortisol levels; under stress, the HPA axis releases corticotrophin-releasing hormone (CRH) to stimulate adrenocorticotropin hormone (ACTH) secretion via the CRH receptor (CRHR) from the anterior pituitary, thereby elevating cortisol. The CRHRs (CRHR1 and CRHR2) and the melanocortin receptors (MC1R-MC5R) mediate the axis responsiveness to integrated signals from diurnal rhythms, cortisol negative feedback via the glucocorticoid receptor, and superimposed stressors. Recently, $M C 2 R$ variants leading to strong responses to ACTH have been described. ${ }^{16}$ Further, $M C 4 R$ variants causing functional impairment have been reported. ${ }^{17}$ Increased cortisol causes serotonergic dysfunction, which is a substrate for depression. ${ }^{12}$ While acute stress with associated cortisol levels is a physiological phenomenon, persistent or chronic stress associated with persistent or chronic hypercortisolism may lead to a pathological condition. Hypercortisolism and altered feedback inhibition are HPA abnormalities of depression, T2D, and MetS (Figure 1). ${ }^{7-9,18}$ Depressed patients, given their hypercortisolism and compared to control subjects, have inappropriately "normal" plasma ACTH and cerebrospinal fluid $\mathrm{CRH} ;{ }^{19}$ that is, their levels should be lower in the presence of high cortisol, which triggers a negative feedback at the level of the hypothalamus and pituitary gland, thereby reducing CRH and ACTH. Thus CRHR, ACTH receptor, and glucocorticoid receptor dysfunctions are possible. Several of these HPA axis receptor genes are associated with metabolic abnormalities; the known physiologic effects of glucocorticoids suggest that inherited predisposition to HPA axis activation may contribute to glucose intolerance, ${ }^{20}$ visceral obesity, and increased triglycerides and blood pressure. ${ }^{21,22}$

It is possible that common gene pathways are responsible for the association of depression with T2D and MetS and that

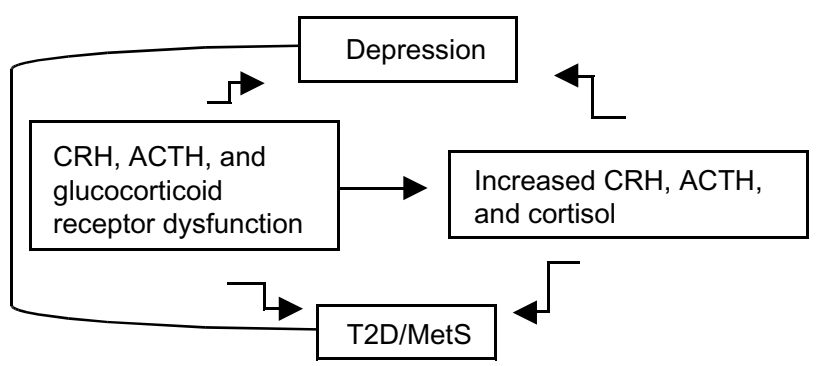

Figure I Hypothesized relationship between $\mathrm{CRH}, \mathrm{ACTH}$, and glucocorticoid receptors dysfunction, increased $\mathrm{CRH}, \mathrm{ACTH}$ and cortisol levels, depression, T2D, and MetS.

Abbreviations: $\mathrm{ACTH}$, adrenocorticotropin hormone; $\mathrm{CRH}$, corticotropinreleasing hormone; MetS, metabolic syndrome; T2D, type 2 diabetes. genetic variation in the HPA axis receptors may explain the link between depression, T2D, and MetS.

\section{T2D, MetS, and depression and possible genetic stratification for their comorbidity}

T2D (with 11\% prevalence after age 50), ${ }^{23}$ MetS (with 42\% prevalence after age 60 ), ${ }^{24}$ and depression (with $9 \%$ prevalence in adults $)^{25}$ are heterogeneous polygenic and complex disorders and they are often comorbid. T2D is defined by at least two fasting glucose levels $\geq 126 \mathrm{mg} / \mathrm{dL}$ or a glucose level of $200 \mathrm{mg} / \mathrm{dL}$ at 2 hours of the oral glucose tolerance test or by a random glucose level of $200 \mathrm{mg} / \mathrm{dL}$ associated with symptoms. MetS is defined by the National Cholesterol Education Program (2002) Adult Treatment Panel III as the presence of at least three of the following: abdominal obesity (waist circumference in men $>102 \mathrm{~cm}$, in women $>88 \mathrm{~cm}$ ), high triglycerides ( $\geq 150 \mathrm{mg} / \mathrm{dL}$ ), low high-density lipoprotein (HDL) cholesterol (HDL $<40 \mathrm{mg} / \mathrm{dL}$ in men, $<50 \mathrm{mg} /$ $\mathrm{dL}$ in women), high blood pressure ( $\geq 130 / 85 \mathrm{mmHg}$ and/or on antihypertensive medications), and high fasting glucose ( $\geq 110 \mathrm{mg} / \mathrm{dL}$ and/or on antidiabetic medications). Visceral fat deposition, high blood pressure, and hyperglycemia are all aging phenomena.

The Diagnostic and Statistical Manual of Mental Disorders, Fifth Edition (DSM-V) criteria for major depressive disorder (depression) are: presence of depressed mood or a loss of interest or pleasure in daily activities for more than 2 weeks; mood change from the person's baseline; impaired function at least either social or occupational or educational. Further, at least five of the following nine symptoms must be present nearly every day: depressed or irritable mood most of the day, nearly every day, per either subjective report (eg, the patient feels sad or empty) or observation made by others (eg, appears tearful); decreased interest or pleasure in most activities, most of each day; significant weight change $(5 \%)$ or change in appetite; change in sleep: insomnia or hypersomnia; change in activity: psychomotor agitation or retardation; fatigue or loss of energy; guilt or worthlessness: feelings of worthlessness or excessive or inappropriate guilt; concentration: diminished ability to think or concentrate, or more indecisiveness; and suicidality: thoughts of death or suicide, or the patient has a suicide plan.

Both the serotonergic and HPA system are implicated in depression ${ }^{26}$ and both may play a role in T2D and MetS. ${ }^{6,27,28}$ Thus, it is unlikely that a single pathway or a few genes in a specific pathway will explain any one of these three disorders or their comorbidity. We believe that there is a genetic stratification in comorbid-diseases predisposition 
correlated to phenotype heterogeneity. As not all depressed patients develop T2D and MetS, and not all patients with T2D and MetS have depression, different gene pathways will be responsible for each disorder independently, but the HPA axis function and underlying genes could be related to the symptoms and signs of depression and potentially contributing to the increased risk for T2D and MetS. However, the genetic risk conferred by the HPA axis pathway for the comorbidity of depression, T2D, and MetS is expected to be stratified in patient groups and to correlate with sub-phenotypes of T2D, MetS, and depression. An investigational study of the correlation of the HPA-axis-related genes with the phenotype(s) of T2D, MetS, and depression, or the lack thereof, may elucidate the genetic basis of the T2D and MetS association with depression. Such an investigational study will provide the foundation upon which other data and pathogenetic hypotheses could subsequently be built.

\section{Novelty of hypothesis and new investigational needs}

Our hypothesis for the potential link of depression with T2D and MetS challenges the currently accepted paradigm that T2D and MetS are only metabolic disorders, and that depression is only a mental disorder. In fact, we believe that they are all, at least partially and in the subgroup of patients with T2D, MetS, and depression comorbidity, associated with hyperactivity of the neuroendocrine cortisol pathway. There are no extensive data regarding genetic screening of the HPA axis receptor genes jointly exploring T2D, MetS, and depression traits in humans. It would be a powerful and innovative strategy for gene risk identification to perform linkage and association tests not only in a group of patients with T2D, MetS, and depression, but also with the pre-phenotypes and associated mental traits potentially contributing to these diseases. The hypothesis is that T2D and MetS are not merely disorders affecting glucose levels, lipid levels, and blood pressure, rather they are complex disorders characterized by increased predisposition to stress-related hyperactivity and abnormal psychological traits leading to abnormal behavioral and compensatory mechanisms.

Ideally, the impact of single and/or complex gene variants should be tested in the major traits as well as in the subphenotypes of these two apparently distinct disorder groups of T2D-MetS and depression. There is a need to test not just genotypes and alleles of candidate genes, but also haplotypes, diplotypes, and multilocus alleles to prove the risk effects of complex gene variants in common disorders.

A linkage strategy would be helpful in identifying rare variants rather than common variants as major players in the diseases' causes. ${ }^{29}$ Also, the interaction among gene variants should be tested.

To test the abovementioned hypothesis, it would be essential to build an interdisciplinary approach of human genetics and clinical phenotyping of T2D and MetS with a focus on depression and related traits and to perform a joint study of the HPA axis receptor genes in both human T2D and MetS with the depression phenotypes.

\section{Implication of the HPA axis and related candidate genes in the pathogenesis of the comorbidity of T2D, MetS, and depression}

High cortisol increases glycogenolysis, gluconeogenesis, insulin resistance, free fatty acids, and visceral obesity, and indirectly and directly reduces insulin secretion; all these effects per se and jointly lead to $\mathrm{T}^{2} \mathrm{D}^{20}$ and MetS. High cortisol may cause depressive symptoms as well ${ }^{30,31}$ and stress plays a major role in depression: early life stress (eg, separation anxiety at an early life stage $)^{32}$ associated with HPA axis hyperactivation ${ }^{14}$ induces long-lasting changes linked to adult anxiety and depressive behavior. ${ }^{33}$ While some subjects thrive and some break down under similar adverse circumstances due to neuroendocrine stress-related psychopathology, differential genetic predisposition to neuroendocrine stress response is expected. The CRH system plays a role in the stress response of depression ${ }^{13,15}$ and $C R H$ single nucleotide polymorphisms are depression risk variants. ${ }^{15}$ The $\mathrm{CRH}$ system resistance leads to hypercortisolism. A subgroup of hypercortisolemic patients with depression, if stimulated with $\mathrm{CRH}$, show a blunted ACTH response, whereas $\mathrm{CRH}$ infusion to healthy subjects reproduces the hypercortisolism of depression, suggesting that hypercortisolism in depression represents a defect at the CRHR level, resulting in $\mathrm{CRH}$ hypersecretion. ${ }^{34}$ Furthermore, a significant cortisol response to a blunted ACTH response suggests that the adrenal glands hyper-respond to ACTH. Thus, there may be an ACTH receptor abnormality as well. ${ }^{35}$ Aging is associated with both the HPA axis reduced feedback and hyperactivity, ${ }^{36}$ which could be due to glucocorticoid receptor resistance, and may lead to T2D, MetS, and depression. However, depression prevalence decreases with age. Consequentially, the stress response pathway may lead to the T2D-depression and MetS-depression comorbidity. The genes possibly conferring predisposition to the clinical association of T2D, MetS, and depression are the CRHRs (CRHR1 and CRHR2), the corticotropin receptors or melanocortin receptors $(M C 1 R-M C 5 R)$, the glucocorticoid receptor $(G C R)$, the mineralocorticoid receptor $(M C R)$, and the FK506 binding protein 51 (FKBP5) (Table 1). 
Table I Candidate genes, their locus and linkage data, and related risk human phenotypes

\begin{tabular}{|c|c|c|}
\hline Gene & Locus; linkage & $\begin{array}{l}\text { Risk variants in } \\
\text { humans }\end{array}$ \\
\hline CRHRI & I7qI2; T2D, MetS & $\begin{array}{l}\text { Depression, } \\
\text { antidepressant response, } \\
\text { hypertension }\end{array}$ \\
\hline CRHR2 & $\begin{array}{l}\text { 7p2I-pI5; T2D, glycemia, } \\
\text { triglyceride, HDL, depression, } \\
\text { bipolar disorder }\end{array}$ & \\
\hline$M C I R$ & $\begin{array}{l}\text { I6q24; bipolar disorder, } \\
\text { diabetic nephropathy, left } \\
\text { ventricular thickness in MetS }\end{array}$ & $\begin{array}{l}\text { Depression, } \\
\text { antidepressant response }\end{array}$ \\
\hline$M C 2 R$ & $\begin{array}{l}\text { I8p I I; bipolar disorder, T2D, } \\
\text { BMI, obesity, insulin }\end{array}$ & $\begin{array}{l}\text { Hypoglycemia, } \\
\text { glucocorticoid deficiency }\end{array}$ \\
\hline$M C 3 R$ & $\begin{array}{l}20 \mathrm{q} \mid 3.2 \text {; bipolar disorder, T2D, } \\
\text { early-onset hypertension in } \\
\text { African-Americans }\end{array}$ & $\begin{array}{l}\text { Obesity, T2D, protective } \\
\text { against increased weight } \\
\text { and blood pressure }\end{array}$ \\
\hline$M C 4 R$ & $\begin{array}{l}\text { I8q22; depression, bipolar } \\
\text { disorder, T2D } \\
\text { I8q22 del metabolic defects; } \\
\text { glycemia, triglyceride, fat mass }\end{array}$ & $\begin{array}{l}\text { Hyperphagia, increased } \\
\text { BMI, } \\
\text { T2D } \\
\text { Weight regulation, } \\
\text { depression }\end{array}$ \\
\hline$M C 5 R$ & $\begin{array}{l}\text { I8pI I; bipolar disorder, T2D, } \\
\text { BMI, obesity, insulin }\end{array}$ & T2D, BMI \\
\hline $\mathrm{NR3Cl}$ & 5q3I; bipolar disorder & $\begin{array}{l}\text { Vulnerability, stress } \\
\text { response, depression, } \\
\text { hyperglycemia, insulin } \\
\text { resistance, T2D } \\
\text { treatment, hypertension }\end{array}$ \\
\hline$N R 3 C 2$ & $\begin{array}{l}\text { 4q3I.I-3।.2; T2D, MetS, bipolar } \\
\text { disorder, blood pressure }\end{array}$ & $\begin{array}{l}\text { Antidepressant response, } \\
\text { depression }\end{array}$ \\
\hline FKBP5 & $\begin{array}{l}6 \mathrm{p} 21.31 ; \mathrm{T} 2 \mathrm{D} \text {, obesity, blood } \\
\text { pressure, bipolar disorder }\end{array}$ & $\begin{array}{l}\text { Depression, } \\
\text { antidepressant response }\end{array}$ \\
\hline
\end{tabular}

Abbreviations: BMI, body mass index; HDL, high-density lipoprotein; MetS, metabolic syndrome; T2D, type 2 diabetes; del, deletion; CRHRI, corticotropin receptor I; CRHR2, corticotropin receptor 2; MCIR, melanocortin receptor I; MC2R, melanocortin receptor 2; MC3R, melanocortin receptor 3; MC4R, melanocortin receptor 4; $\mathrm{MC5R}$, melanocortin receptor 5 ; $\mathrm{NR3CI}$, glucocorticoid receptor I; NR3C2, mineralcorticoid receptor 2; FKBP5, FK506 binding protein 5.

The CRHR1 gene is expressed in the brain. CRHR1-/mice show reduced anxiety behavior. ${ }^{37,38}$ CRHRl variants are implicated in human depression ${ }^{39-42}$ and antidepressant response. ${ }^{43,44}$ However, there are no studies in human T2D and MetS. CRHR1 is expressed on beta cells and stimulates beta cell proliferation and insulin secretion in a glucosedependent manner, ${ }^{45}$ some $C R H R 1$ variants are associated with hypertension, ${ }^{46}$ thus CRHR1 dysfunction may lead to hyperglycemia, T2D, and high blood pressure of MetS. Interestingly, the CRHR1 genetic locus $17 \mathrm{q} 12$ is linked to $\mathrm{T}^{2} \mathrm{D}^{47}$ and MetS. ${ }^{48}$

The $C R H R 2$ gene is also expressed in the brain. CRHR2-/mice have reduced stress coping behaviors ${ }^{49}$ and show hypersensitivity to stress and anxiety behavior. ${ }^{50,51}$ CRHR2 is not yet identified as a risk gene in human depression, ${ }^{52} \mathrm{~T} 2 \mathrm{D}$, or
MetS. However, previous studies report the CRHR2 locus 7p21-p15 in linkage with depression ${ }^{53}$ and bipolar disorder. ${ }^{54,55}$ Of note, genetic overlap exists between bipolar disorder and depression. ${ }^{56}$ The CRHR 2 genetic locus $7 \mathrm{p} 21-\mathrm{p} 15$ is also linked to $\mathrm{T} 2 \mathrm{D},{ }^{57,58}$ glycemia, triglyceride, and HDL levels. ${ }^{59}$ CRHR2-/- mice show high blood pressure and reduced sustained hypophagia; ${ }^{49}$ thus $C R H R 2$ variants may lead to high blood pressure and obesity of MetS, the latter potentially due to impaired mediation of food intake control.

The corticotropin receptor or melanocortin 1 receptor $(M C 1 R)$ gene is expressed in the brain, liver, and pancreas, and is implicated in depression and antidepressant response. ${ }^{60}$ However, there are no studies in human genetics of T2D or MetS. The MC1R genetic locus 16q24 is linked to bipolar disorder, ${ }^{61,62} \mathrm{~T} 2 \mathrm{D}$ nephropathy, ${ }^{63}$ and left ventricular thickness in the setting of MetS. ${ }^{64}$

The corticotropin receptor or melanocortin 2 receptor $(M C 2 R)$ gene is expressed in the brain and adrenal gland; $M C 2 R$ mutations cause hypoglycemia and glucocorticoid deficiency ${ }^{65}$ There is a lack of studies in human depression and T2D. The $M C 2 R$ genetic locus $18 \mathrm{p} 11$ is linked to bipolar disorder, ${ }^{67-70} \mathrm{~T} 2 \mathrm{D}$, insulin, obesity, and body mass index (BMI). ${ }^{71-75}$

The corticotropin receptor or melanocortin 3 receptor $(M C 3 R)$ gene is expressed in the hypothalamus and brain; it is involved in obesity ${ }^{76,77}$ and may play a role in human T2D. ${ }^{66,78} M C 3 R-/-$ mice have increased adipose mass; ${ }^{79}$ $M C 3 R$ variants may protect against weight and blood pressure increase. ${ }^{80}$ There are no studies in human MetS and depression. The $M C 3 R$ genetic locus $20 \mathrm{q} 13.2$ is linked to bipolar disorder, ${ }^{55} \mathrm{~T} 2 \mathrm{D},{ }^{81-83}$ and early-onset hypertension in African Americans. ${ }^{84}$

The corticotropin receptor or melanocortin 4 receptor $(M C 4 R)$ gene is expressed in the brain; it is involved in hyperphagia and increased $\mathrm{BMI},{ }^{85}$ as well as $\mathrm{T} 2 \mathrm{D},{ }^{86-89}$ but data are inconsistent. ${ }^{90,91}$ Some $M C 4 R$ variants are implicated in weight regulation and BMI. ${ }^{92,93} M C 4 R$ is also implicated in depression. ${ }^{94}$ The $M C 4 R$ genetic locus $18 \mathrm{q} 22$ is linked to depression, ${ }^{53}$ bipolar disorder ${ }^{67,69}$ and T2D. ${ }^{71}$ It is known that $18 \mathrm{q} 22$ deletion causes metabolic defects. ${ }^{95}$ The $18 \mathrm{q} 22$ locus affects glycemia,${ }^{96}$ is linked to hypertriglyceridemia,${ }^{97}$ and is associated with fat mass. ${ }^{98}$

The corticotropin receptor or melanocortin 5 receptor $(M C 5 R)$ gene is expressed in the brain and has a role in T2D. ${ }^{66} M C 5 R$ variants are associated with BMI. ${ }^{98}$ There is a lack of studies regarding depression. The $M C 5 R$ genetic locus $18 \mathrm{p} 11$ is linked to bipolar disorder, ${ }^{67-69} \mathrm{~T} 2 \mathrm{D},{ }^{71-73} \mathrm{BMI},{ }^{75}$ obesity, and insulin. ${ }^{74}$ 
The glucocorticoid receptor gene or nuclear receptor sub-family 3, group C, member 1 (GCR or $N R 3 C 1$ ), expressed ubiquitously, and the mineralocorticoid receptor gene or nuclear receptor sub-family 3, group $\mathrm{C}$, member 2 (MCR or NR3C2), expressed in multiple tissues including the central nervous system and the hippocampus, may also predispose to the T2D, MetS, and depression comorbidity. Glucocorticoids mediate the HPA axis negative feedback via the GCR at the hypothalamus and pituitary level. Cortisol has effects on both MCR and GCR. Of note, the GCR locus $5 \mathrm{q} 31$ is associated to hypertension ${ }^{99}$ and linked to bipolar disorder. ${ }^{100}$ The $M C R$ locus chromosome $4 \mathrm{q} 31.1-31.2$ is linked to T2D and MetS ${ }^{101}$ and to bipolar disorder. ${ }^{102-105}$ $M C R$ and $G C R$ variants affect coping style and depression vulnerability, antidepressants response, stress, and depression endocrine response. ${ }^{106-115} M C R$ expression is increased in the hypothalamus of diabetic rats ${ }^{116}$ and $M C R$ is linked to blood pressure. ${ }^{117} \mathrm{GCR}$ affects glucose levels ${ }^{118}$ and is associated with insulin resistance, ${ }^{119} \mathrm{GCR}$ antagonism improves insulin sensitivity. ${ }^{120}$ Thus, GCR and $M C R$ dysfunction may lead to depression, T2D, and MetS, and contribute to the comorbidity of these three disorders.

In addition, the FK506 binding protein 5 (FKBP5), a heat shock protein 90 co-chaperone of the steroid receptor complex and component of the chaperone receptor heterocomplex, reduces ligand sensitivity of the $\mathrm{GCR}^{121}$ and is implicated in cortisol effects. Interestingly, the FKBP 5 gene locus $6 \mathrm{p} 21.31$ is associated to $\mathrm{T} 2 \mathrm{D}^{122}$ and linked to obesity, ${ }^{123}$ blood pressure, ${ }^{124}$ and bipolar disorder. ${ }^{125}$ The gene FKBP5 is therefore a candidate gene for the comorbidity of T2D, MetS, and depression. FKBP5 has in fact been implicated in depression ${ }^{126,127}$ and antidepressant response, ${ }^{128}$ even if results for antidepressant response are conflicting. ${ }^{29}$ There are not yet data on FKBP5 and T2D and MetS.

For all the above-mentioned reasons, these genes alone or jointly may confer the genetic susceptibility to the HPA axis hyperactivation under stressful circumstance and cause depression and confer increased risk for the T2D and MetS phenotypes.

\section{Suggested methods to empower gene identification for the comorbidity of depression, T2D, and MetS}

\section{Families phenotyping}

Ideally, to identify the gene variants in the HPA axis receptor genes responsible for the clinical association of depression,
T2D, and MetS, families with all three disorders, as well with only two and one disorder, should be studied. At best, recruiting families with early onset of disease phenotypes and their comorbidity will increase the genetic load for risk predisposition and the probability to discover the susceptibility gene variants. The families should be characterized not only for depression but also for associated traits such as anxiety, insomnia, symptom duration and severity, substance abuse and dependence, life stress level, and resilience. The cases should be characterized for disease severity, age of onset, associated mental comorbidities, subtype of melancholic depression and atypical depression, to empower gene identification strategy and to link risk gene variants to specific traits. Melancholic depression is characterized by the following: depressed mood; anhedonia as per loss of pleasure in most or all activities, inability to react to pleasurable stimuli; insomnia or early-morning waking; symptom worsening in the morning hours; psychomotor agitation or retardation; excessive or inappropriate guilt, worthlessness; fatigue; decreased appetite and excessive weight loss; and inattention or poor concentration. Atypical depression is characterized by the following: improved mood in response to positive events; irritable-anxious mood; increased appetite as per comfort eating or significant weight gain; sensation of heaviness in the limbs; hypersomnia as per excessive sleep or sleepiness; over-sensitivity to perceived interpersonal rejection causing significant social impairment. ${ }^{130}$

Similarly the families should not only be characterized for T2D but also for all the T2D-associated common phenotypes, including, but not only, behavioral and compensatory mechanisms related to stress, nutrition, and physical exercise. In the characterization of MetS, beyond the classical features of MetS, other potentially associated traits should be included; for example psychological traits, behavioral traits, nutrition and exercise preferences, sleep duration and quality, and quality of life.

\section{Linkage and association tests}

By characterizing the families with all three disorders, and with only two or one of them, as well as defining new groups of traits potentially associated with the disease comorbidity, it would then be feasible to create different categories of joint endophenotypes and traits and to test them for linkage and association with the gene variants under study. The creation of categories with T2D and melancholic or atypical depression or both or with specific depression traits (eg, anhedonia, insomnia, psychomotor agitation or retardation, decreased appetite), psychoactive medication intake, earlier age of onset, 
extreme phenotype severity, and life stress level, will enrich the genetic load and likelihood for stress-related risk-gene identification, which could be compared with one category with either only T2D or a depression trait. Similarly, it would be helpful to test gene variants for linkage with MetS (as traditionally defined) as well as for just single phenotypes of high blood pressure, visceral obesity, high triglycerides, and low HDL, and for the positivity of only two phenotypes; and for the additional presence of depression, anxiety, insomnia, and therapy with antipsychotics, antidepressants, and anxiolytics. To increase the probability of discovering risk-genes, the linkage tests should also be performed on a group of families with severe MetS by including at least four positive criteria as well as increasing the criteria threshold (eg, BMI $>35$, blood pressure $>160 / 95 \mathrm{mmHg}$, and triglycerides $>200 \mathrm{mg} / \mathrm{dL}$ ), with the addition of depression, anxiety, insomnia, psychotropic medications, and high level of stress. By creating a subject category for multiple MetS-depression traits, the probability that those families will carry the gene variants related to chronic stress vulnerability and HPA axis hyperactivation will be greater, as well as the chance to identify those gene variants compared to: either a category with only two MetS traits; or one MetS trait or depression trait; or neither MetS nor a depression trait.

Another helpful method to identify the gene variants responsible for the comorbidity of depression, T2D, and MetS is to perform variance-component trait analyses for each quantitative trait associated with T2D and mentalbehavioral traits (eg, stress, sleep duration and quality, diet, physical activity, and medication compliance), using the other available traits as covariates. The metabolic quantitative traits for T2D could be basal glucose levels at T2D onset, average glycated hemoglobin 1c \% (Hba1c\%) levels, total cholesterol and low-density lipoprotein levels, age at disease onset, BMI at onset, and years of therapy defined by diet only, oral hypoglycemic agents only, insulin only, and insulin combined with oral hypoglycemic agents. For the MetS phenotype, the quantitative traits could be blood pressure, waist circumference, maximum life BMI, triglycerides, HDL, and glucose levels, both independently and by using these traits as covariates with age and sex. Further, phenotypes of depression, anxiety, insomnia and, psychotropic medication, could be used as covariates. Another approach could be to test gene variants for linkage with a newly created quantitative scale with: depression, anxiety, insomnia, psychotropic medication use, pre-diabetes, T2D, hypertension, high triglycerides, low HDL, and visceral obesity. For the depression phenotype, the quantitative traits could be age of onset, number of DSM-V criteria met, quantification of severity of episodes, associated mental diseases, and treatment types and years of antidepressant therapy.

Both linkage and association tests should be performed using the nonparametric and parametric methods and data should be validated with random simulations. Linkage analysis should also be conditioned on the presence of already identified loci.

The association tests should be performed with alleles, genotypes, haplotypes, and diplotypes; in fact when two or more adjacent single variant polymorphisms are considered, haplotype analysis is crucial since single variant polymorphisms may affect complex traits acting as cis-regulatory elements. In addition, haplotype analysis is more powerful than single variant polymorphisms analysis. ${ }^{131}$ Epistatic interaction ought to be studied as well, as a disorder often involves a multifactorial underpinning to which many genes contribute, and evidence shows that the effects of some genes are not additive; rather, the effects are via interactions or epistasis. ${ }^{132,133}$ Because of epistasis, two or more genes may increase or reduce disease risk more than expected from their independent effects.

If large case-control groups are used, to avoid false negative associations, association tests should be performed with case subjects positive for comorbid diseases or a trait category against control subjects negative for those comorbid diseases or trait category. In fact, if a gene variant causes depression, T2D, and MetS, it would be difficult to identify it by association unless the case group is enriched of those phenotypes and the control group is unaffected by all those phenotypes. For diseaseassociated quantitative traits (eg, $\mathrm{Hba} 1 \mathrm{c} \%$ ), logistic regression analysis should be performed.

If association is not identified, the tests should be repeated with the probands of only the families showing a positive linkage, in order to increase the likelihood of gene identification. In fact, those families with a positive linkage are more likely to carry the disease variant and to highlight a positive association if tested against a control group. ${ }^{134}$

\section{T2D-depression and MetS- depression reciprocity}

The T2D and depression association should be, for some genes and gene variants and with different significance levels, comparable to the MetS and depression association. However, some discordance is expected that, if identified, could guide into gene risk stratification for the T2D, MetS, and depression comorbidity. Thus, while some families with T2D-depression and/or MetS-depression will have shared 
gene-risk vulnerability within the cortisol pathway, other families will not show genetic susceptibility within the cortisol pathway and will likely present phenotype differences.

However, for the gene variants not contributing to the T2D-depression and MetS-depression association, linkage and association within just T2D-MetS or depression could be present. Ultimately, some genes and gene variants will contribute neither to T2D-MetS comorbidity with depression nor to T2D-MetS or depression. In fact, some variability in the genetic burden ofT2D, MetS, and depression is expected, and once identified will help in defining more homogeneous clinical phenotypes for future studies by increasing gene risk detection power.

\section{Other studies and possible outcomes}

It would be interesting to set up epigenetic studies to explore in depth the hypothesis that stress may indeed induce functional regulatory changes in the abovementioned candidate genes, which may per se lead to hypercortisolism and to the comorbidity of depression, T2D, and MetS. Furthermore, to fully assess the impact of depression on T2D and MetS and study the comorbidity and interaction of these three disorders phenomenon, it would be ideal to perform longitudinal studies to determine the conferring risk of one disorder onto the other.

The final goal of our proposed studies would be to implement preventive plans targeting subjects identified at risk for T2D, MetS, and depression, who, by knowing their genetic make-up and risk for such disorders, may be inclined to undergo behavioral-cognitive therapy treatments and lifestyle modifying behaviors. Such preventive plans may significantly decrease the burden of T2D, MetS, and depression comorbidity on subjects and on the health care system. In the long-term, it would be possible to therapeutically target the receptors implicated in the HPA axis disruption in subjects at risk for T2D, MetS, and depression, thereby reversing the HPA axis hyperactivity to a physiological state, and preventing the comorbidity of T2D, MetS, and depression. The results of a study targeting the abovementioned comorbidity should prompt new research in the area of associated mental and metabolic disorders, thereby creating a new focus on the neuroendocrinemental-metabolic dysfunctions, which may characterize pre-disease states. In order to advance the research in the field of T2D, MetS, and depression, there is a need to accept the idea of a joint pathogenesis of such apparently different disorders.

\section{Disclosure}

The author reports no conflicts of interest in this work.

\section{References}

1. Demakakos P, Pierce MB, Hardy R. Depressive symptoms and risk of type 2 diabetes in a national sample of middle-aged and older adults: the English longitudinal study of aging. Diabetes Care. 2010;33(4): 792-797.

2. Rustad JK, Musselman DL, Nemeroff CB. The relationship of depression and diabetes: Pathophysiological and treatment implications. Psychoneuroendocrinology. 2011;36(9):1276-1286.

3. Mezuk B, Eaton WW, Albrecht S, Golden SH. Depression and type 2 diabetes over the lifespan: a meta-analysis. Diabetes Care. 2008;31(12): 2383-2390.

4. Pan A, Lucas M, Sun Q, et al. Bidirectional association between depression and type 2 diabetes mellitus in women. Arch Intern Med. 2010;170(21):1884-1891.

5. Mangold D, Marino E, Javors M. The cortisol awakening response predicts subclinical depressive symptomatology in Mexican American adults. J Psychiatr Res. 2011;45(7):902-909.

6. Vogelzangs N, Suthers K, Ferrucci L, et al. Hypercortisolemic depression is associated with the metabolic syndrome in late-life. Psychoneuroendocrinology. 2007;32(2):151-159.

7. Björntorp P. The origins and consequences of obesity. Diabetes. Ciba Found Symp. 1996;201:68-80; discussion 80-89, 188-193.

8. Bruehl H, Rueger M, Dziobek I, et al. Hypothalamic-pituitary-adrenal axis dysregulation and memory impairments in type 2 diabetes. $J$ Clin Endocrinol Metab. 2007;92(7):2439-2445.

9. Vinson GP. Angiotensin II, corticosteroids, type II diabetes and the metabolic syndrome. Med Hypotheses. 2007;68(6):1200-1207.

10. Björntorp P, Holm G, Rosmond R. Hypothalamic arousal, insulin resistance and Type 2 diabetes mellitus. Diabet Med. 1999;16(5): 373-383.

11. Wolkowitz OM, Reus VI, Mellon SH. Of sound mind and body: depression, disease, and accelerated aging. Dialogues Clin Neurosci. 2011;13(1):25-39.

12. Pompili M, Serafini G, Innamorati M, et al. The hypothalamic-pituitaryadrenal axis and serotonin abnormalities: a selective overview for the implications of suicide prevention. Eur Arch Psychiatry Clin Neurosci. 2010;260(8):583-600.

13. Keck ME. Corticotropin-releasing factor, vasopressin and receptor systems in depression and anxiety. Amino Acids. 2006;31(3): 241-250.

14. Naert G, Ixart G, Maurice T, Tapia-Arancibia L, Givalois L. Brain-derived neurotrophic factor and hypothalamic-pituitary-adrenal axis adaptation processes in a depressive-like state induced by chronic restraint stress. Mol Cell Neurosci. 2011;46(1):55-66.

15. Bao AM, Swaab DF. Corticotropin-releasing hormone and arginine vasopressin in depression focus on the human postmortem hypothalamus. Vitam Horm. 2010;82:339-365.

16. Ding YX, Zou LP, He B, Yue WH, Liu ZL, Zhang D. ACTH receptor (MC2R) promoter variants associated with infantile spasms modulate $\mathrm{MC} 2 \mathrm{R}$ expression and responsiveness to ACTH. Pharmacogenet Genomics. 2010;20(2):71-76.

17. Hinney A, Bettecken T, Tarnow P, et al. Prevalence, spectrum, and functional characterization of melanocortin-4 receptor gene mutations in a representative population-based sample and obese adults from Germany. J Clin Endocrinol Metab. 2006;91(5):1761-1769.

18. Zunszain PA, Anacker C, Cattaneo A, Carvalho LA, Pariante CM. Glucocorticoids, cytokines and brain abnormalities in depression. Prog Neuropsychopharmacol Biol Psychiatry. 2011;35(3):722-729.

19. Wong ML, Kling MA, Munson PJ, et al. Pronounced and sustained central hypernoradrenergic function in major depression with melancholic features: relation to hypercortisolism and corticotropin-releasing hormone. Proc Natl Acad Sci U S A. 2000;97(1):325-330. 
20. Pivonello R, De Leo M, Vitale P, et al. Pathophysiology of diabetes mellitus in Cushing's syndrome. Neuroendocrinology. 2010;92 Suppl $1: 77-81$.

21. Wallerius S, Rosmond R, Ljung T, Holm G, Björntorp P. Rise in morning saliva cortisol is associated with abdominal obesity in men: a preliminary report. J Endocrinol Invest. 2003;26(7):616-619.

22. Weigensberg MJ, Toledo-Corral CM, Goran MI. Association between the metabolic syndrome and serum cortisol in overweight Latino youth. J Clin Endocrinol Metab. 2008;93(4):1372-1378.

23. Mokdad AH, Ford ES, Bowman BA, et al. Prevalence of obesity, diabetes, and obesity-related health risk factors, 2001. JAMA. 2003;289(1):76-79.

24. Ford ES, Giles WH, Dietz WH. Prevalence of the metabolic syndrome among US adults: findings from the third National Health and Nutrition Examination Survey. JAMA. 2002;287(3):356-359.

25. Centers for Disease Control and Prevention. Current depression among adults - United States, 2006 and 2008. MMWR Morb Mortal Wkly Rep. 2010;59(38):1229-1235.

26. Lanfumey L, Mongeau R, Cohen-Salmon C, Hamon M. Corticosteroidserotonin interactions in the neurobiological mechanisms of stressrelated disorders. Neurosci Biobehav Rev. 2008;32(6):1174-1184.

27. Price JC, Kelley DE, Ryan CM, et al. Evidence of increased serotonin1A receptor binding in type 2 diabetes: a positron emission tomography study. Brain Res. 2002;927(1):97-103.

28. Silić A, Karlović D, Serretti A. Increased inflammation and lower platelet 5-HT in depression with metabolic syndrome. J Affect Disord. 2012;141(1):72-78.

29. Dickson SP, Wang K, Krantz I, Hakonarson H, Goldstein DB. Rare variants create synthetic genome-wide associations. PLoS Biol. 2010;8(1):e1000294.

30. Vogelzangs N, Beekman AT, Dik MG, et al. Late-life depression, cortisol, and the metabolic syndrome. Am J Geriatr Psychiatry. 2009;17(8): 716-721.

31. Vogelzangs N, Penninx BW. [Depressive symptoms, cortisol, visceral fat and metabolic syndrome]. Tijdschr Psychiatr. 2011;53(9):613-620. Dutch.

32. Brand S, Wilhelm FH, Kossowsky J, Holsboer-Trachsler E, Schneider S. Children suffering from separation anxiety disorder (SAD) show increased HPA axis activity compared to healthy controls. J Psychiatr Res. 2011;45(4):452-459.

33. Kolber BJ, Boyle MP, Wieczorek L, et al. Transient early-life forebrain corticotropin-releasing hormone elevation causes long-lasting anxiogenic and despair-like changes in mice. $J$ Neurosci. 2010;30(7):2571-2581.

34. Gold PW, Kling MA, Khan I, et al. Corticotropin releasing hormone: relevance to normal physiology and to the pathophysiology and differential diagnosis of hypercortisolism and adrenal insufficiency. Adv Biochem Psychopharmacol. 1987;43:183-200.

35. Clark AJ, Metherell LA. Mechanisms of disease: the adrenocorticotropin receptor and disease. Nat Clin Pract Endocrinol Metab. 2006;2(5): 282-290.

36. Björntorp P. Alterations in the ageing corticotropic stress-response axis. Novartis Found Symp. 2002;242:46-58; discussion 58-65.

37. Timpl P, Spanagel R, Sillaber I, et al. Impaired stress response and reduced anxiety in mice lacking a functional corticotropin-releasing hormone receptor 1. Nat Genet. 1998;19(2):162-166.

38. Smith GW, Aubry JM, Dellu F, et al. Corticotropin releasing factor receptor 1-deficient mice display decreased anxiety, impaired stress response, and aberrant neuroendocrine development. Neuron. 1998;20(6):1093-1102.

39. Heim C, Bradley B, Mletzko TC, et al. Effect of Childhood Trauma on Adult Depression and Neuroendocrine Function: Sex-Specific Moderation by CRH Receptor 1 Gene. Front Behav Neurosci. 2009;3:41.

40. Ressler KJ, Bradley B, Mercer KB, et al. Polymorphisms in CRHR1 and the serotonin transporter loci: gene $\mathrm{x}$ gene $\mathrm{x}$ environment interactions on depressive symptoms. Am J Med Genet B Neuropsychiatr Genet. 2010;153B(3):812-824.
41. Wasserman D, Wasserman J, Rozanov V, Sokolowski M. Depression in suicidal males: genetic risk variants in the CRHR1 gene. Genes Brain Behav. 2009;8(1):72-79.

42. Liu Z, Zhu F, Wang G, et al. Association of corticotropin-releasing hormone receptor1 gene SNP and haplotype with major depression. Neurosci Lett. 2006;404(3):358-362.

43. Licinio J, O'Kirwan F, Irizarry K, et al. Association of a corticotropin-releasing hormone receptor 1 haplotype and antidepressant treatment response in Mexican-Americans. Mol Psychiatry. 2004;9(12): $1075-1082$.

44. Liu Z, Zhu F, Wang G, et al. Association study of corticotropin-releasing hormone receptor 1 gene polymorphisms and antidepressant response in major depressive disorders. Neurosci Lett. 2007;414(2):155-158.

45. Huising MO, van der Meulen T, Vaughan JM, et al. CRFR1 is expressed on pancreatic beta cells, promotes beta cell proliferation, and potentiates insulin secretion in a glucose-dependent manner. Proc Natl Acad Sci U SA. 2010;107(2):912-917.

46. Kamdem LK, Hamilton L, Cheng C, et al. Genetic predictors of glucocorticoid-induced hypertension in children with acute lymphoblastic leukemia. Pharmacogenet Genomics. 2008;18(6):507-514.

47. Spurdle AB, Thompson DJ, Ahmed S, et al; Australian National Endometrial Cancer Study Group; National Study of Endometrial Cancer Genetics Group. Genome-wide association study identifies a common variant associated with risk of endometrial cancer. Nat Genet. 2011;43(5):451-454.

48. Cheng CY, Lee KE, Duggal P, et al. Genome-wide linkage analysis of multiple metabolic factors: evidence of genetic heterogeneity. Obesity (Silver Spring). 2010;18(1):146-152.

49. Coste SC, Kesterson RA, Heldwein KA, et al. Abnormal adaptations to stress and impaired cardiovascular function in mice lacking corticotropin-releasing hormone receptor-2. Nat Genet. 2000;24(4): 403-409.

50. Bale TL, Contarino A, Smith GW, et al. Mice deficient for corticotropinreleasing hormone receptor-2 display anxiety-like behaviour and are hypersensitive to stress. Nat Genet. 2000;24(4):410-414.

51. Kishimoto T, Radulovic J, Radulovic M, et al. Deletion of crhr2 reveals an anxiolytic role for corticotropin-releasing hormone receptor-2. Nat Genet. 2000;24(4):415-419.

52. Villafuerte SM, Del-Favero J, Adolfsson R, et al. Gene-based SNP genetic association study of the corticotropin-releasing hormone receptor-2 (CRHR2) in major depression. Am J Med Genet. 2002;114(2): 222-226.

53. Camp NJ, Lowry MR, Richards RL, et al. Genome-wide linkage analyses of extended Utah pedigrees identifies loci that influence recurrent, early-onset major depression and anxiety disorders. $\mathrm{Am} J$ Med Genet B Neuropsychiatr Genet. 2005;135B(1):85-93.

54. Kremeyer B, Garcia J, Muller H, et al. Genome-wide linkage scan of bipolar disorder in a colombian population isolate replicates Loci on chromosomes 7p21-22, 1p31,16p12 and 21q21-22 and identifies a novel locus on chromosome 12q. Hum Hered. 2010;70(4):255-268.

55. Hamshere ML, Schulze TG, Schumacher J, et al. Mood-incongruent psychosis in bipolar disorder: conditional linkage analysis shows genome-wide suggestive linkage at 1q32.3, 7p13 and 20q13.31. Bipolar Disord. 2009;11(6):610-620.

56. Pregelj P. Psychosis and depression - a neurobiological view. Psychiatr Danub. 2009;21 Suppl 1:102-105.

57. Wiltshire S, Hattersley AT, Hitman GA, et al. A genomewide scan for loci predisposing to type 2 diabetes in a UK population (the Diabetes UK Warren 2 Repository): analysis of 573 pedigrees provides independent replication of a susceptibility locus on chromosome 1q. Am J Hum Genet. 2001;69(3):553-569.

58. Leak TS, Langefeld CD, Keene KL, et al. Chromosome $7 \mathrm{p}$ linkage and association study for diabetes related traits and type 2 diabetes in an African-American population enriched for nephropathy. BMC Med Genet. 2010;11:22. 
59. Tam CH, Lam VK, So WY, Ma RC, Chan JC, Ng MC. Genome-wide linkage scan for factors of metabolic syndrome in a Chinese population. BMC Genet. 2010;11:14.

60. Wu GS, Luo HR, Dong C, Mastronardi C, Licinio J, Wong ML. Sequence polymorphisms of MC1R gene and their association with depression and antidepressant response. Psychiatr Genet. 2011;21(1):14-18.

61. Cheng R, Juo SH, Loth JE, et al. Genome-wide linkage scan in a large bipolar disorder sample from the National Institute of Mental Health genetics initiative suggests putative loci for bipolar disorder, psychosis suicide, and panic disorder. Mol Psychiatry. 2006;11(3):252-260.

62. Hayden EP, Nurnberger JI Jr. Molecular genetics of bipolar disorder. Genes Brain Behav. 2006;5(1):85-95.

63. Chen G, Adeyemo AA, Zhou J, et al. A genome-wide search for linkage to renal function phenotypes in West Africans with type 2 diabetes Am J Kidney Dis. 2007;49(3):394-400.

64. Kraja AT, Huang P, Tang W, et al. QTLs of factors of the metabolic syndrome and echocardiographic phenotypes: the hypertension genetic epidemiology network study. BMC Med Genet. 2008;9:103.

65. Clark AJ, McLoughlin L, Grossman A. Familial glucocorticoid deficiency associated with point mutation in the adrenocorticotropin receptor. Lancet. 1993;341(8843):461-462.

66. Valli-Jaakola K, Suviolahti E, Schalin-Jantti C, et al. Further evidence for the role of ENPP1 in obesity: association with morbid obesity in Finns. Obesity (Silver Spring). 2008;16(9):2113-2119.

67. Baron M. Manic-depression genes and the new millennium: poised for discovery. Mol Psychiatry. 2002;7(4):342-358.

68. Detera-Wadleigh SD, Badner JA, Berrettini WH, et al. A high-density genome scan detects evidence for a bipolar-disorder susceptibility locus on 13q32 and other potential loci on 1q32 and 18p11.2. Proc Natl Acad Sci USA. 1999;96(10):5604-5609.

69. Nothen MM, Cichon S, Rohleder H, et al. Evaluation of linkage of bipolar affective disorder to chromosome 18 in a sample of 57 German families. Mol Psychiatry. 1999;4(1):76-84.

70. Segurado R, Detera-Wadleigh SD, Levinson DF, et al. Genome scan meta-analysis of schizophrenia and bipolar disorder, part III: Bipolar disorder. Am J Hum Genet. 2003;73(1):49-62.

71. Jun G, Song Y, Stein CM, Iyengar SK. An autosome-wide search using longitudinal data for loci linked to type 2 diabetes progression. $B M C$ Genet. 2003;4 Suppl 1:S8.

72. van Tilburg JH, Sandkuijl LA, Franke L, et al. Genome-wide screen in obese pedigrees with type 2 diabetes mellitus from a defined Dutch population. Eur J Clin Invest. 2003;33(12):1070-1074.

73. Parker A, Meyer J, Lewitzky S, et al. A gene conferring susceptibility to type 2 diabetes in conjunction with obesity is located on chromosome 18p11. Diabetes. 2001;50(3):675-680.

74. Kraja AT, Rao DC, Weder AB, et al. Two major QTLs and several others relate to factors of metabolic syndrome in the family blood pressure program. Hypertension. 2005;46(4):751-757.

75. Shmulewitz D, Heath SC, Blundell ML, et al. Linkage analysis of quantitative traits for obesity, diabetes, hypertension, and dyslipidemia on the island of Kosrae, Federated States of Micronesia. Proc Natl Acad Sci USA. 2006;103(10):3502-3509.

76. Feng N, Young SF, Aguilera G, et al. Co-occurrence of two partially inactivating polymorphisms of MC3R is associated with pediatric-onset obesity. Diabetes. 2005;54(9):2663-2667.

77. Mencarelli M, Walker GE, Maestrini S, et al. Sporadic mutations in melanocortin receptor 3 in morbid obese individuals. Eur J Hum Genet. 2008;16(5):581-586.

78. Hani EH, Dupont S, Durand E, et al. Naturally occurring mutations in the melanocortin receptor 3 gene are not associated with type 2 diabetes mellitus in French Caucasians. J Clin Endocrinol Metab. 2001;86(6):2895-2898.

79. Butler AA, Kesterson RA, Khong K, et al. A unique metabolic syndrome causes obesity in the melanocortin-3 receptor-deficient mouse. Endocrinology. 2000;141(9):3518-3521.
80. Yako YY, Fanampe BL, Hassan SM, Erasmus RT, van der Merwe L, Matsha TE. Negative association of MC3R variants with weight and blood pressure in Cape Town pupils aged 11-16 years. S Afr Med J. 2011;101(6):417-420.

81. Klupa T, Malecki MT, Pezzolesi M, et al. Further evidence for a susceptibility locus for type 2 diabetes on chromosome 20q13.1-q13.2. Diabetes. 2000;49(12):2212-2216.

82. Bento JL, Palmer ND, Zhong M, et al. Heterogeneity in gene loci associated with type 2 diabetes on human chromosome $20 q 13.1$. Genomics. 2008;92(4):226-234.

83. Zouali H, Hani EH, Philippi A, et al. A susceptibility locus for early-onset non-insulin dependent (type 2) diabetes mellitus maps to chromosome $20 \mathrm{q}$, proximal to the phosphoenolpyruvate carboxykinase gene. Hum Mol Genet. 1997;6(9):1401-1408.

84. Freedman BI, Langefeld CD, Rich SS, et al. A genome scan for ESRD in black families enriched for nondiabetic nephropathy. J Am Soc Nephrol. 2004;15(10):2719-2727.

85. Luan J, Kerner B, Zhao JH, et al. A multilevel linear mixed model of the association between candidate genes and weight and body mass index using the Framingham longitudinal family data. BMC Proc. 2009 ; 3 Suppl 7:S115.

86. Butler AA, Cone RD. The melanocortin receptors: lessons from knockout models. Neuropeptides. 2002;36(2-3):77-84.

87. Wen J, Ronn T, Olsson A, et al. Investigation of type 2 diabetes risk alleles support CDKN2A/B, CDKAL1, and TCF7L2 as susceptibility genes in a Han Chinese cohort. PLoS One. 2010;5(2):e9153.

88. Qi L, Kraft P, Hunter DJ, Hu FB. The common obesity variant near MC4R gene is associated with higher intakes of total energy and dietary fat, weight change and diabetes risk in women. Hum Mol Genet. 2008;17(22):3502-3508.

89. Mergen M, Mergen H, Ozata M, Oner R, Oner C. A novel melanocortin 4 receptor (MC4R) gene mutation associated with morbid obesity. $J$ Clin Endocrinol Metab. 2001;86(7):3448.

90. Ohshiro Y, Sanke T, Ueda K, et al. Molecular scanning for mutations in the melanocortin-4 receptor gene in obese/diabetic Japanese. Ann Hum Genet. 1999;63(Pt 6):483-487.

91. Zakel UA, Wudy SA, Heinzel-Gutenbrunner M, et al. [Prevalence of melanocortin 4 receptor (MC4R) mutations and polymorphismsin consecutively ascertained obese children and adolescents from a pediatric health care utilization population]. Klin Padiatr. 2005;217(4):244249. German.

92. Povel CM, Boer JM, Onland-Moret NC, Dollé ME, Feskens EJ, van der Schouw YT. Single nucleotide polymorphisms (SNPs) involved in insulin resistance, weight regulation, lipid metabolism and inflammation in relation to metabolic syndrome: an epidemiological study. Cardiovasc Diabetol. 2012;11:133.

93. Ewens KG, Jones MR, Ankener W, et al. FTO and MC4R gene variants are associated with obesity in polycystic ovary syndrome. PLoS One. 2011;6(1):e16390.

94. Chaki S, Okuyama S. Involvement of melanocortin-4 receptor in anxiety and depression. Peptides. 2005;26(10):1952-1964.

95. Silverman GA, Schneider SS, Massa HF, et al. The 18q- syndrome: analysis of chromosomes by bivariate flow karyotyping and the PCR reveals a successive set of deletion breakpoints within 18q21.2-q22.2 Am J Hum Genet. 1995;56(4):926-937.

96. Li WD, Dong C, Li D, Garrigan C, Price RA. A quantitative trait locus influencing fasting plasma glucose in chromosome region 18q22-23. Diabetes. 2004;53(9):2487-2491.

97. Shah SH, Kraus WE, Crossman DC, et al. Serum lipids in the GENECARD study of coronary artery disease identify quantitative trait loci and phenotypic subsets on chromosomes $3 \mathrm{q}$ and 5q. Ann Hum Genet. 2006;70(Pt 6):738-748.

98. Chagnon YC, Chen WJ, Perusse L, et al. Linkage and association studies between the melanocortin receptors 4 and 5 genes and obesity-related phenotypes in the Quebec Family Study. Mol Med. 1997;3(10): 663-673. 
99. Guo Y, Tomlinson B, Chu T, et al. A genome-wide linkage and association scan reveals novel loci for hypertension and blood pressure traits. PLoS One. 2012;7(2):e31489.

100. Herzberg I, Jasinska A, Garcia J, et al. Convergent linkage evidence from two Latin-American population isolates supports the presence of a susceptibility locus for bipolar disorder in 5q31-34. Hum Mol Genet. 2006;15(21):3146-3153.

101. Bowden DW, Rudock M, Ziegler J, et al. Coincident linkage of type 2 diabetes, metabolic syndrome, and measures of cardiovascular disease in a genome scan of the diabetes heart study. Diabetes. 2006;55(7): 1985-1994.

102. $\mathrm{Xu} \mathrm{H}$, Cheng R, Juo SH, et al. Fine mapping of candidate regions for bipolar disorder provides strong evidence for susceptibility loci on chromosomes 7q. Am J Med Genet B Neuropsychiatr Genet. 2011;156(2):168-176.

103. Kaneva R, Milanova V, Angelicheva D, et al. Bipolar disorder in the Bulgarian Gypsies: genetic heterogeneity in a young founder population. Am J Med Genet B Neuropsychiatr Genet. 2009;150B(2): 191-201.

104. Schumacher J, Kaneva R, Jamra RA, et al. Genomewide scan and fine-mapping linkage studies in four European samples with bipolar affective disorder suggest a new susceptibility locus on chromosome 1p35-p36 and provides further evidence of loci on chromosome 4q31 and 6q24. Am J Hum Genet. 2005;77(6):1102-1111.

105. Liu J, Juo SH, Dewan A, et al. Evidence for a putative bipolar disorder locus on 2p13-16 and other potential loci on 4q31, 7q34, 8q13, 9q31, 10q21-24, 13q32, 14q21 and 17q11-12. Mol Psychiatry. 2003;8(3): 333-342.

106. Derijk RH, de Kloet ER. Corticosteroid receptor polymorphisms: determinants of vulnerability and resilience. Eur J Pharmacol. 2008;583(2-3):303-311.

107. Derijk RH, van Leeuwen N, Klok MD, Zitman FG. Corticosteroid receptor-gene variants: modulators of the stress-response and implications for mental health. Eur J Pharmacol. 2008;585(2-3): 492-501.

108. Klok MD, Vreeburg SA, Penninx BW, Zitman FG, de Kloet ER, DeRijk RH. Common functional mineralocorticoid receptor polymorphisms modulate the cortisol awakening response: Interaction with SSRIs. Psychoneuroendocrinology. 2011;36(4):484-494.

109. Kumsta R, Moser D, Streit F, Koper JW, Meyer J, Wüst S. Characterization of a glucocorticoid receptor gene (GR, NR3C1) promoter polymorphism reveals functionality and extends a haplotype with putative clinical relevance. Am J Med Genet B Neuropsychiatr Genet. 2009;150B(4):476-482.

110. Lahti J, Räikkönen K, Bruce S, et al. Glucocorticoid receptor gene haplotype predicts increased risk of hospital admission for depressive disorders in the Helsinki birth cohort study. J Psychiatr Res. 2011;45(9):1160-1164.

111. DeRijk RH, de KloetER, Zitman FG, van Leeuwen N. Mineralocorticoid receptor gene variants as determinants of HPA axis regulation and behavior. Endocr Dev. 2011;20:137-148.

112. Klok MD, Giltay EJ, Van der Does AJ, et al. A common and functional mineralocorticoid receptor haplotype enhances optimism and protects against depression in females. Transl Psychiatry. 2011;1:e62.

113. Szczepankiewicz A, Leszczyńska-Rodziewicz A, Pawlak J, et al. Glucocorticoid receptor polymorphism is associated with major depression and predominance of depression in the course of bipolar disorder. $J$ Affect Disord. 2011;134(1-3):138-144.

114. Zobel A, Jessen F, von Widdern O, et al. Unipolar depression and hippocampal volume: impact of DNA sequence variants of the glucocorticoid receptor gene. Am J Med Genet B Neuropsychiatr Genet. 2008;147B(6):836-843.

115. Uher R, Huezo-Diaz P, Perroud N, et al. Genetic predictors of response to antidepressants in the GENDEP project. Pharmacogenomics $J$. 2009;9(4):225-233.
116. Jöhren O, Dendorfer A, Dominiak P, Raasch W. Gene expression of mineralocorticoid and glucocorticoid receptors in the limbic system is related to type-2 like diabetes in leptin-resistant rats. Brain Res. 2007;1184:160-167.

117. Arenas IA, Tremblay J, Deslauriers B, et al. Dynamic genetic linkage of intermediate blood pressure phenotypes during postural adaptations in a founder population. Physiol Genomics. 2013;45(4):138-150.

118. Liang Y, Osborne MC, Monia BP, et al. Antisense oligonucleotides targeted against glucocorticoid receptor reduce hepatic glucose production and ameliorate hyperglycemia in diabetic mice. Metabolism. 2005;54(7):848-855.

119. Syed AA, Halpin CG, Irving JA, et al. A common intron 2 polymorphism of the glucocorticoid receptor gene is associated with insulin resistance in men. Clin Endocrinol (Oxf). 2008;68(6):879-884.

120. Tomlinson JW, Stewart PM. Modulation of glucocorticoid action and the treatment of type-2 diabetes. Best Pract Res Clin Endocrinol Metab. 2007;21(4):607-619.

121. Jääskelainen T, Makkonen H, Palvimo JJ. Steroid up-regulation of FKBP51 and its role in hormone signaling. Curr Opin Pharmacol. 2011;11(4):326-331.

122. Lu F, Qian Y, Li H, et al. Genetic variants on chromosome 6p21.1 and 6 p22.3 are associated with type 2 diabetes risk: a case-control study in Han Chinese. J Hum Genet. 2012;57(5):320-325.

123. Bouchard C, Pérusse L. Current status of the human obesity gene map. Obes Res. 1996;4(1):81-90.

124. Zintzaras E, Kitsios G, Kent D, et al. Genome-wide scans meta-analysis for pulse pressure. Hypertension. 2007;50(3):557-564.

125. Doyle AE, Biederman J, Ferreira MA, Wong P, Smoller JW, Faraone SV. Suggestive linkage of the child behavior checklist juvenile bipolar disorder phenotype to 1p21,6p21, and 8q21. JAm Acad Child Adolesc Psychiatry. 2010;49(4):378-387.

126. O'Leary JC, Zhang B, Koren J, Blair L, Dickey CA. The Role of FKBP5 in Mood Disorders: Action of FKBP5 on Steroid Hormone Receptors Leads to Questions About its Evolutionary Importance. CNS Neurol Disord Drug Targets. Epub September 4, 2013.

127. Seifuddin F, Pirooznia M, Judy JT, Goes FS, Potash JB, Zandi PP. Systematic review of genome-wide gene expression studies of bipolar disorder. BMC Psychiatry. 2013;13:213.

128. Horstmann S, Lucae S, Menke A, et al. Polymorphisms in GRIK4, HTR2A, and FKBP5 show interactive effects in predicting remission to antidepressant treatment. Neuropsychopharmacology. 2010;35(3): 727-740.

129. Sarginson JE, Lazzeroni LC, Ryan HS, Schatzberg AF, Murphy GM Jr. FKBP5 polymorphisms and antidepressant response in geriatric depression. Am J Med Genet B Neuropsychiatr Genet. 2009;153B(2): 554-560.

130. American Psychiatry Association. Diagnostic and Statistical Manual of Mental Disorders. 4th ed (Text Rev). Washington, DC. 2000:419-422.

131. Schaid DJ, Rowland CM, Tines DE, Jacobson RM, Poland GA. Score tests for association between traits and haplotypes when linkage phase is ambiguous. Am J Hum Genet. 2002;70(2):425-434.

132. Martin MP, Gao X, Lee JH, et al. Epistatic interaction between KIR3DS1 and HLA-B delays the progression to AIDS. Nat Genet. 2002;31(4):429-434.

133. Gabutero E, Moore C, Mallal S, Stewart G, Williamson P. Interaction between allelic variation in IL12B and CCR 5 affects the development of AIDS: IL12B/CCR5 interaction and HIV/AIDS. AIDS. 2007;21(1): 65-69.

134. Milord E, Gragnoli C. NEUROG3 variants and type 2 diabetes in Italians. Minerva Med. 2006;97(5):373-378. 
The Application of Clinical Genetics

\section{Publish your work in this journal}

The Application of Clinical Genetics is an international, peer-reviewed open access journal that welcomes laboratory and clinical findings in the field of human genetics. Specific topics include: Population genetics; Functional genetics; Natural history of genetic disease; Management of genetic disease; Mechanisms of genetic disease; Counseling and ethical

issues; Animal models; Pharmacogenetics; Prenatal diagnosis; Dysmorphology. The manuscript management system is completely online and includes a very quick and fair peer-review system, which is all easy to use. Visit http://www.dovepress.com/testimonials.php to read real quotes from published authors.

Submit your manuscript here: http://www.dovepress.com/the-application-of-clinical-genetics-journa 